\title{
APPROXIMATION TO A MODEL OF GOVERNANCE IN PUBLIC UNIVERSITIES OF THE PROVINCE OF PICHINCHA OF ECUADOR
}

\author{
Betzabé del Rosario Maldonado Mera \\ University of the Armed Forces ESPE \\ Sangolquí - Ecuador \\ brmaldonado@espe.edu.ec
}

\author{
José Javier Buenaño Cabrera \\ University of the Armed Forces ESPE \\ Sangolquí - Ecuador \\ iibuenanio@espe.edu.ec
}

\author{
Karla Viviana Benavides Espinosa \\ University of the Armed Forces ESPE \\ Sangolquí - Ecuador \\ kvbenavides@espe.edu.ec
}

Reception Date: 03/109/2019 - Approval Date: 05/31/2019

\section{ABSTRACT}

In the last decade, Ecuador's higher education system observes substantial changes, whose dynamics has stressed marked transformations within universities. This work follows the research from the perspective of internal governance, to make an approach to the prevailing models in universities involved in the study. The analysis considers a systemic approach, where the term governance is associated with the government's ability to define the work of higher education institutions and forms of internal organization to fulfill the role granted. The study is documentary type eminently qualitative, based on sources of information obtained from official websites of universities and various higher education organizations. In a complementary manner, a questionnaire was applied through a survey to advisers from the same institutions to confirm or contrast the conclusions generated. The principles of governance considered in the study are autonomy, academic freedom, accountability, participation and institutional representation. The results show that the control mechanisms implemented by the State influence within universities and shape differences in models exercised governance.

KEY WORDS: University governance; University autonomy; Higher education.

\section{INTRODUCCIÓN}

The first section of the Constitution of Ecuador addresses the field of education.

\footnotetext{
"Visión de Futuro" Año 16, Volumen N²3 N², Julio - Diciembre 2019 - Pág. 122 - 137

URL de la Revista: http://visiondefuturo.fce.unam.edu.ar/index.php/visiondefuturo/index

URL del Documento: http://visiondefuturo.fce.unam.edu.ar/index.php/visiondefuturo/issue/view/16

ISSN 1668 - 8708 - Versión en Línea

E-mail: revistacientifica@fce.unam.edu.ar
} 
Determines that education is a public service and guarantees the active participation of all and free higher education. Emphasizes that education is governed by the principles of joint government, equal opportunities, quality, relevance, breadth, universal thinking and scientific production of global technology (Asamblea Constituyente, 2008).

Under the regulatory framework governing the higher education system (SES) in Ecuador before 2008, the Higher Education Institutions (IES) exercised an absolute university autonomy in all its essential functions. Condition that led to insufficient university quality, which is evidenced by the results of the first evaluation in the same year by the competent authority (CONEA, 2009).

These results were decisive in defining government policies aimed at improving the SES. A comprehensive regulatory framework governing the actions of the IES and incorporates principles which should underpin the responsible exercise of university autonomy, accountability and participation in national planning was generated.

The dynamics of transformation observed in the SES extend to the internal governance of IES, according Brunner \& Ganga (2016) these "must adapt to the new conditions of crowded systems, more complex organizations" (p.15), characteristics that match with those observed in the Ecuadorian system.

In this context, the questions arise: What are the principles of internal governance considered in the university context? In addition, what are the observed practices that shape governance models in the IES studied during the period 2008 - 2018?

The objective of this research is to identify the governance model that approximates each of the public universities domiciled in the Province of Pichincha. Since this proposal will lead to several studies that promote synergies among actors to establish an effective governance model in public HEls.

The paper is organized as follows. A literature review of several authors exposed versed in the subject of study, to identify different models of university governance from an internal perspective. Observing governance principles as dimensions or fields of study, from which variables required for the collection of information are defined. Later research methodology and then the results of document analysis and surveys of college counselors exposed. We conclude pointing out the prevailing model of governance in each of the IES involved in the study.

\footnotetext{
"Visión de Futuro" Año 16, Volumen Nº 23 N², Julio - Diciembre 2019 - Pág. 122 - 137

URL de la Revista: http://visiondefuturo.fce.unam.edu.ar/index.php/visiondefuturo/index

URL del Documento: http://visiondefuturo.fce.unam.edu.ar/index.php/visiondefuturo/issue/view/16

ISSN 1668 - 8708 - Versión en Línea

E-mail: revistacientifica@fce.unam.edu.ar
} 


\section{DEVELOPMENT}

\section{University governance}

The term governance translated into Spanish as governance, is Anglo-American origin and spread in the early nineties. Mayntz (2006) defines it as "all forms assumed by the collective regulation of social issues, from civil self-regulation, through various forms of joint action by state and private actors to operate exclusively state actors" (p. 104).

View governance beyond the figure of the State is seen as a new form of government, between different levels of government and those with external organizations with whom it interacts (Prats, 2016). From this approach, the governance process involving various stakeholders, government, civil society and business, producing a government network of interaction between the public, private and civil sector (Carrasco, 2017).

In the field of higher education, governance has been one of the main factors considered in the modernization agenda, because it not only affects internal aspects of university management, but also linked to the role of the State and the various external actors (Endika, 2012).

Rhodes (1996) addresses education governance from a vision of networks, where relationships between different industry players is essential, government policy is known and interaction spaces organized, government, political, business and social groups are established. This conception has its beginnings in the 1970s to 1980 , in which the UK government exercised a process of state policies agreed with government actors and nongovernmental (Santizo Rodall, 2011).

Gayle, Tewarie and White (2011) argue that governance refers to the structure and decision making in universities whose implications affect internal agents such as, governing bodies, budget approvals, procurement, among others. As well as external agencies are established by higher state bodies.

The concept of university governance proposed by Brower (2015) relates to the procedures, which allow the horizontal interaction of different public and private actors. Necessary dynamics in the field of higher education viable social agreements and fulfill the mission of the university as such.

Alcantara (2012) agrees with these views and notes that governance in the field of higher education, is a set of formal and informal settings that make possible the decisionmaking and implementation of actions. In addition, it is possible to analyze it from the national level and from the institutional. What differentiates between external governance

\footnotetext{
"Visión de Futuro" Año 16, Volumen N²3 N², Julio - Diciembre 2019 - Pág. 122 - 137

URL de la Revista: http://visiondefuturo.fce.unam.edu.ar/index.php/visiondefuturo/index

URL del Documento: http://visiondefuturo.fce.unam.edu.ar/index.php/visiondefuturo/issue/view/16

ISSN 1668 - 8708 - Versión en Línea

E-mail: revistacientifica@fce.unam.edu.ar
} 
and internal governance? External governance occupies individual relationships with each IES governing bodies, while internal governance, educational system of lines of authority within the IES.

From the systemic perspective, the observed diversity in higher education institutions in their typology and objectives incorporates a significant level of complexity makes it difficult to have a governance model and quality control, more suitable for university management.

This work follows the research from the perspective of internal governance, to make an approach to those prevailing in each of the IES involved in the study models. The analysis is done from a systemic approach, where university governance is associated with the ability of the government to define the work of the IES (top-down). How well they organized internally to fulfill the role given in education is observed, focusing the analysis on setting government at the institutional level (button-up).

\section{Models of university governance}

From the perspective of internal university governance, four models from "functions exercised by agencies that are on the cusp of the university structure and how they relate to those who are hierarchically below it" are distinguished (Uauy Duarte, Barraza, \& Rivas, 2014, p. 10).

The model of university governance efficientist Regulatory $(A)$ corresponds to a type of government whose function is eminently executive and eficientista conformation. Regulatory contrast model is participatory (C). However, in the model Executive efficientist (B), functions are mainly normative and shaping eficientista, contrast is effective participatory model (D). The present study approach to governance model of the IES is based on this proposal.

The proposal considers that there are two HEls governance structures, the central structure comprising decision-making bodies and local structures corresponding to different scales of division of academic units. Division that often takes forms of faculties, departments, among others. As is the case of the three universities involved in this investigation.

\section{Governance principles in the field of higher education}

According to Ganga, Quiroz and Fossatti (2017), from studies of Leslie (1975), Barrett (1963), Moran (1971), Peterson (1971), Pfnister (1970) and Richardson (1974), university governance It has to do with stakeholders, participation, elements of government level or context and administrative matters.

Cifuentes et al (2016) establishes specific dimensions of university governance, university autonomy, relevance, quality, planning and financing. Castro and Gairín (2013)

\footnotetext{
"Visión de Futuro" Año 16, Volumen N²3 N², Julio - Diciembre 2019 - Pág. 122 - 137

URL de la Revista: http://visiondefuturo.fce.unam.edu.ar/index.php/visiondefuturo/index

URL del Documento: http://visiondefuturo.fce.unam.edu.ar/index.php/visiondefuturo/issue/view/16

ISSN 1668 - 8708 - Versión en Línea

E-mail: revistacientifica@fce.unam.edu.ar
} 
defined as principles of university governance, university autonomy, academic freedom, accountability, participation and institutional representation. This study takes into account these principles to the extent that they are addressed in the regulatory body that regulates the Ecuadorian higher education system.

University autonomy: Article 355 of the Constitution of the Republic of Ecuador, states that "The State recognizes the universities and polytechnics autonomy academic, administrative, financial and organizational, in line with the objectives of development regime and the principles established in the Constitution ... "(Asamblea Constituyente, 2008).

The LOES Article 18 states that responsible autonomy is: independence for teachers and researchers exercise academic freedom and research, freedom to issue its charter, develop plans and curricula, appoint teaching staff, learning fulfilling alternation and gender equality, manage their internal processes, approve its internal budget, manage their assets, manage their resources and ability to determine its forms and governing bodies (Asamblea Nacional, 2010).

Accountability: The LOES in Articles 25 and 27 determines that the IES must submit annual accounts on the fulfillment of its purposes and use of public funds received, to the General Comptroller of the State, SENESCYT and Higher Education Council, its observance is performed by the Rector (National Assembly, 2010). You may think that university freedom is linked to better internal management efficiency, an assurance of academic and research quality and a better response to the industry it serves.

Accountability represents transparency on the performance of institutions, allowing students, entrepreneurs and other stakeholders are kept informed. Internally the IES also benefit from transparency as a means of feedback for decision-making (Bengoetxea, 2012).

Academic Freedom: Marin (2011) points out that academic freedom "within the law is autonomy to challenge and question received wisdom, raise other thoughts and support different and controversial or unpopular opinions without that means you lose your position in the IES" (p. 208). But by relying on government budget allocations that requires accountability and improve efficiency, it can result in academic mediocrity.

Participation and institutional representation: The exercise of university autonomy is founded on the co-government, the Organic Law on Higher Education (LOES) Article 45 defines the co-government as the shared management of the IES keeping the principles of quality, alternation and equal opportunities, by of different stakeholders, teachers, students and administrative staff.

\footnotetext{
"Visión de Futuro" Año 16, Volumen No 23 N², Julio - Diciembre 2019 - Pág. 122 - 137

URL de la Revista: http://visiondefuturo.fce.unam.edu.ar/index.php/visiondefuturo/index

URL del Documento: http://visiondefuturo.fce.unam.edu.ar/index.php/visiondefuturo/issue/view/16

ISSN 1668 - 8708 - Versión en Línea

E-mail: revistacientifica@fce.unam.edu.ar
} 


\section{Research Methodology}

The research is descriptive with survey bibliographic information obtained from official websites of higher education institutions involved in the study and various state entities. HEls are considered domiciled public in the province of Pichincha, University of the Armed Forces (ESPE), Central University of Ecuador (UCE) and the National Polytechnic School (EPN).

Following Prats (2016) research was conducted from an internal perspective, each IES official documents issued by the Honorable Council Polytechnic University and, minutes, resolutions, reports and legislation passed by this establishment were analyzed.

To refine the study it applied a questionnaire survey by institutional advisers with expert knowledge of university management and SES objectively contributed to the research. The questionnaire was divided into two parts, one with open criteria to identify informants on the concept and principles of governance questions. The second part leading to quantify the indicators related to the exercise of governance within each IES closed questions.

From this information an analysis is performed to bring the model of internal governance of IES one of the four models of university governance proposed by Uauy and others (2014).

Table $\mathrm{N}^{\circ} 1$ governance dimensions and variables considered in the study, the same as indicators related to models governance IES and SES are described. The dimensions correspond to the governance principles defined by Castro \& Gairín (2013).

Table №1. Dimensions and Variables Governance

\begin{tabular}{ll}
\hline \multicolumn{1}{c}{ Dimensions } & \multicolumn{1}{c}{ variables } \\
\hline university autonomy & Internal regulations \\
\cline { 2 - 2 } & strategic and operational plan \\
\cline { 2 - 2 } & Budget \\
\cline { 2 - 2 } & university structure \\
\hline interagency agreements & Property management \\
\hline Academic freedom & Inference government agencies \\
\hline & Undergraduate and graduate careers \\
\cline { 2 - 2 } & honorifics \\
\cline { 2 - 2 } & Pedagogical model \\
\cline { 2 - 2 } & Racing programs with other IES \\
\cline { 2 - 2 } & Extensions or offices \\
\cline { 2 - 2 } & Hiring teachers and students \\
\hline Accountability & detailed and complete information \\
\hline & Transparency \\
\hline
\end{tabular}

\footnotetext{
"Visión de Futuro" Año 16, Volumen N² 23 N², Julio - Diciembre 2019 - Pág. 122 - 137

URL de la Revista: http://visiondefuturo.fce.unam.edu.ar/index.php/visiondefuturo/index

URL del Documento: http://visiondefuturo.fce.unam.edu.ar/index.php/visiondefuturo/issue/view/16

ISSN 1668 - 8708 - Versión en Línea

E-mail: revistacientifica@fce.unam.edu.ar
} 


\begin{tabular}{|c|c|}
\hline & Media \\
\hline \multirow{4}{*}{$\begin{array}{l}\text { Participation and institutional } \\
\text { representation }\end{array}$} & corporate bodies - co-government \\
\hline & Forming unions \\
\hline & Discrimination ethnicity, gender, religion, etc. \\
\hline & Rights of the university community \\
\hline
\end{tabular}

Source: Prepared by considering the principles of Castro \& Gairín (2013)

Compliance verification of variables is performed through the review of various media listed in Table $\mathrm{N}^{\circ} 2$.

Table $\mathbf{N}^{\circ}$ 2. Verification means of variables university governance

\begin{tabular}{|c|c|c|}
\hline Verification means & Indicators & Description \\
\hline \multirow{4}{*}{$\begin{array}{l}\text { Document } \\
\text { Verification }\end{array}$} & Availability & IES has the formal document referenced by each of the \\
\hline & & variables \\
\hline & external approval & Document reacted to the external variable requires approval \\
\hline & Organism & If you require external approval, an agency that approves \\
\hline \multirow[t]{3}{*}{ Verification rules } & statute & \multirow{3}{*}{$\begin{array}{l}\text { internal legal framework considers the issues observed in the } \\
\text { variables }\end{array}$} \\
\hline & regulations & \\
\hline & instructive & \\
\hline \multirow{3}{*}{$\begin{array}{l}\text { Verification Superior } \\
\text { Collegiate Body }\end{array}$} & Proceedings & Evidence that the judicial panel tries Superior variables \\
\hline & & related issues \\
\hline & resolutions & \\
\hline \multirow{2}{*}{$\begin{array}{l}\text { Verification external } \\
\text { linkage }\end{array}$} & contracts & IES evidence that links with external actors \\
\hline & conventions & \\
\hline
\end{tabular}

Source: Own Elaboration

\section{Results}

\section{Document review results}

In the first instance the evidence related to the principles of university governance were analyzed. From Table $\mathrm{N}^{\circ} 3$ Table $\mathrm{N}^{\circ} 6$ to the findings in ESPE, which in most UCE match and EPN are summarized. The most important difference is that in EPN and UCE has organizations of students, teachers and workers, while only ESPE teachers' associations and workers.

The UCE has no strategic plan or educational model; these are in the process of formulation. Their actions are guided through an improvement plan formulated in 2014, which caters strictly to the observations of CEAACES (2015) because of institutional evaluation, which placed in category $\mathrm{B}$.

\footnotetext{
"Visión de Futuro" Año 16, Volumen N²3 N², Julio - Diciembre 2019 - Pág. 122 - 137

URL de la Revista: http://visiondefuturo.fce.unam.edu.ar/index.php/visiondefuturo/index

URL del Documento: http://visiondefuturo.fce.unam.edu.ar/index.php/visiondefuturo/issue/view/16

ISSN 1668 - 8708 - Versión en Línea

E-mail: revistacientifica@fce.unam.edu.ar
} 
The order imposed by the SES required the IES changes in several areas, arrangements for admission and access, diversity of supply, modes of study, performance evaluation, curricular architecture, mechanisms for quality assurance, budget distribution, among others. This situation coincides with the analysis by Brunner (2012) who notes that the pressures they are subjected affect the IES changing the very concept of college.

In addition, Ganga, Abello \& Quiroz (2014) emphasize the new idea of community and new forms of relationship with the environment. Hence the importance of complementing the study to determine the prevailing model of governance in the SES and its impact on the path of transformation of IES.

Table $N^{\circ}$ 3. Autonomy verification principle, ESPE 2016

\begin{tabular}{|c|c|c|c|c|c|c|c|c|c|c|c|}
\hline \multirow{2}{*}{ University autonomy } & \multicolumn{2}{|c|}{$\begin{array}{l}\text { document } \\
\text { provides }\end{array}$} & \multicolumn{2}{|c|}{$\begin{array}{c}\text { It requires } \\
\text { external approval }\end{array}$} & \multirow{2}{*}{ 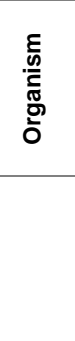 } & \multirow{2}{*}{$\sum_{\frac{ \pm}{3}}^{\frac{\pi}{\omega}}$} & \multirow{2}{*}{ 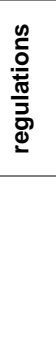 } & \multirow{2}{*}{ 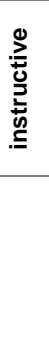 } & \multicolumn{2}{|c|}{$\begin{array}{l}\text { Superior of the } \\
\text { College }\end{array}$} & \multirow[t]{2}{*}{ Observations } \\
\hline & YES & $\begin{array}{l}\text { DO } \\
\text { NOT }\end{array}$ & YES & $\begin{array}{l}\text { DO } \\
\text { NOT }\end{array}$ & & & & & 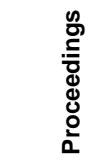 & 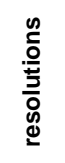 & \\
\hline \multirow[t]{2}{*}{ Internal regulations } & $x$ & & $x$ & & CES & $x$ & & & $x$ & & $\begin{array}{l}\text { The Statute requires approval of the } \\
\text { HCU internal and external of the } \\
\text { CES. }\end{array}$ \\
\hline & & & & & & & & & & & $\begin{array}{l}\text { It has internal regulations governing } \\
\text { various fields. }\end{array}$ \\
\hline \multirow[t]{2}{*}{$\begin{array}{l}\text { strategic and } \\
\text { operational plan }\end{array}$} & $\mathrm{X}$ & & & $\mathrm{X}$ & & $\mathrm{X}$ & $X$ & $\mathrm{X}$ & $\mathrm{X}$ & $\mathrm{X}$ & $\begin{array}{l}\text { Statute provides powers of } \\
\text { formulation, approval, modification } \\
\text { plans. }\end{array}$ \\
\hline & & & & & & & & & & & $\begin{array}{l}\text { Organic Regulations Organizational } \\
\text { Process Management, pinpoints } \\
\text { powers in this area. Instructions } \\
\text { with guidelines for implementation } \\
\text { of plans. }\end{array}$ \\
\hline Budget & $\mathrm{X}$ & & $\mathrm{X}$ & & 虫 & $X$ & $X$ & & $X$ & $\mathrm{X}$ & $\begin{array}{l}\text { The budget allocated by the CES is } \\
\text { distributed within the IES, however } \\
\text { the National Secretariat of Planning } \\
\text { and Development approves } \\
\text { investment projects. The LOES } \\
\text { determines the percentage of the } \\
\text { budget that the IES must be } \\
\text { assigned to certain priority areas } \\
\text { such as scholarships and research. }\end{array}$ \\
\hline university structure & $\mathrm{X}$ & & $\mathrm{X}$ & & CES & $\mathrm{X}$ & $\mathrm{X}$ & & $\mathrm{X}$ & & $\begin{array}{l}\text { The university structure consists in } \\
\text { the Statute and delves into its duties } \\
\text { and powers in the respective } \\
\text { internal regulations. }\end{array}$ \\
\hline $\begin{array}{l}\text { interagency } \\
\text { agreements, contracts }\end{array}$ & $x$ & & & $x$ & & $\mathrm{X}$ & $X$ & $\mathrm{X}$ & $\mathrm{X}$ & $X$ & $\begin{array}{l}\text { The LOES provides that the CES } \\
\text { approved agreements for joint } \\
\text { programs with foreign universities. }\end{array}$ \\
\hline property management & $\mathrm{X}$ & & & $\mathrm{X}$ & & $\mathrm{X}$ & $x$ & & & & \\
\hline $\begin{array}{l}\text { Tampering government } \\
\text { agencies }\end{array}$ & $X$ & & & & & & & & & & $\begin{array}{l}\text { Government agencies resolutions } \\
\text { refer to IES that are strictly } \\
\text { enforced. }\end{array}$ \\
\hline
\end{tabular}

Source: Own Elaboration

The results of verification of evidence shown by the indicators set for the beginning Autonomy at the University of the Armed Forces ESPE

\footnotetext{
"Visión de Futuro" Año 16, Volumen N²3 N², Julio - Diciembre 2019 - Pág. 122 - 137

URL de la Revista: http://visiondefuturo.fce.unam.edu.ar/index.php/visiondefuturo/index

URL del Documento: http://visiondefuturo.fce.unam.edu.ar/index.php/visiondefuturo/issue/view/16

ISSN 1668 - 8708 - Versión en Línea

E-mail: revistacientifica@fce.unam.edu.ar
} 
Table $N^{\circ}$ 4. Verification principle Academic Freedom, ESPE 2016

\begin{tabular}{|c|c|c|c|c|c|c|c|c|c|c|c|}
\hline \multirow{2}{*}{$\begin{array}{l}\text { Academic } \\
\text { freedom }\end{array}$} & \multicolumn{2}{|c|}{$\begin{array}{l}\text { document } \\
\text { provides }\end{array}$} & \multicolumn{2}{|c|}{$\begin{array}{l}\text { It requires } \\
\text { external } \\
\text { approval }\end{array}$} & \multirow{2}{*}{ 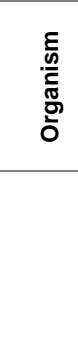 } & \multirow{2}{*}{ 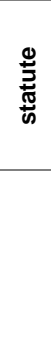 } & \multirow{2}{*}{ 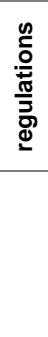 } & \multirow{2}{*}{ 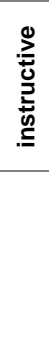 } & \multicolumn{2}{|c|}{$\begin{array}{l}\text { Superior of } \\
\text { the College }\end{array}$} & \multirow[t]{2}{*}{ Observations } \\
\hline & YES & $\begin{array}{l}\text { DO } \\
\text { NO } \\
\text { T }\end{array}$ & YES & $\begin{array}{l}\text { DO } \\
\text { NOT }\end{array}$ & & & & & 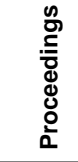 & 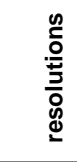 & \\
\hline $\begin{array}{l}\text { Undergradu } \\
\text { ate and } \\
\text { graduate } \\
\text { programs }\end{array}$ & $x$ & & $x$ & & CES & $X$ & $x$ & $x$ & $x$ & $x$ & $\begin{array}{l}\text { Designs and redesigns program, } \\
\text { approved in the HCU and sent to CES for } \\
\text { final approval. }\end{array}$ \\
\hline honorifics & $X$ & & $X$ & & CES & $X$ & & & $X$ & $X$ & \\
\hline $\begin{array}{l}\text { educational } \\
\text { model }\end{array}$ & $X$ & & $x$ & & CES & & $X$ & $X$ & $X$ & $x$ & $\begin{array}{l}\text { CES educational model issues guidelines } \\
\text { to be followed by IES contains guide } \\
\text { designs and redesigns. }\end{array}$ \\
\hline $\begin{array}{l}\text { Racing } \\
\text { programs } \\
\text { with other } \\
\text { IES }\end{array}$ & $\mathrm{X}$ & & $x$ & & CES & $X$ & $x$ & $\mathrm{X}$ & $x$ & $\mathrm{X}$ & $\begin{array}{l}\text { The LOES provides that the CES } \\
\text { approved agreements for joint programs } \\
\text { with foreign universities. }\end{array}$ \\
\hline $\begin{array}{l}\text { Extensions } \\
\text { or offices }\end{array}$ & $X$ & & $X$ & & CES & $\mathrm{X}$ & $X$ & & $x$ & $X$ & \\
\hline $\begin{array}{l}\text { Hiring } \\
\text { teachers and } \\
\text { students }\end{array}$ & $x$ & & & & & $x$ & $x$ & $x$ & $x$ & $x$ & \\
\hline
\end{tabular}

Source: Own Elaboration

Table $\mathbf{N}^{\circ}$ 5. Verification principle Accountability ESPE 2016

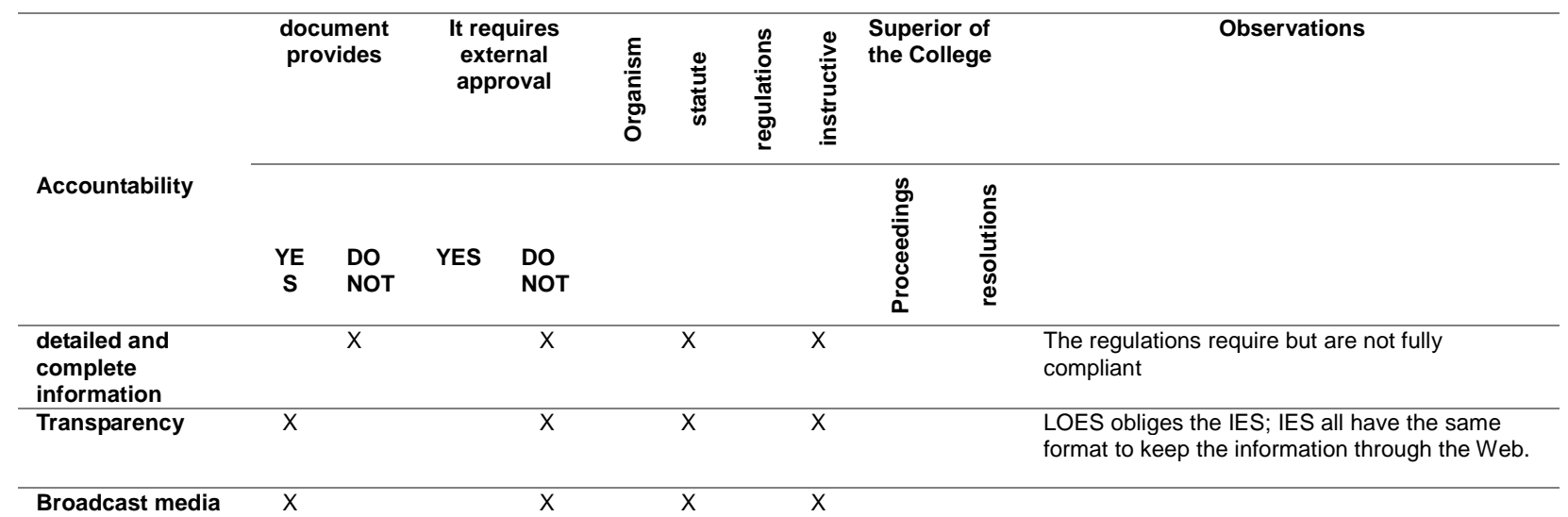

Verification results shown evidence according to the indicators set for Accountability principle of Accounts at the University of the Armed Forces ESPE.

Source: Own Elaboration

\footnotetext{
"Visión de Futuro" Año 16, Volumen N²3 N², Julio - Diciembre 2019 - Pág. 122 - 137

URL de la Revista: http://visiondefuturo.fce.unam.edu.ar/index.php/visiondefuturo/index

URL del Documento: http://visiondefuturo.fce.unam.edu.ar/index.php/visiondefuturo/issue/view/16

ISSN 1668 - 8708 - Versión en Línea

E-mail: revistacientifica@fce.unam.edu.ar
} 
Table $\mathbf{N}^{\circ}$ 6. Verification principle Academic Freedom ESPE 2016

\begin{tabular}{|c|c|c|c|c|c|c|c|c|c|c|c|}
\hline \multirow{2}{*}{$\begin{array}{l}\text { Participation and } \\
\text { institutional } \\
\text { representation }\end{array}$} & \multicolumn{2}{|c|}{$\begin{array}{l}\text { document } \\
\text { provides }\end{array}$} & \multicolumn{2}{|c|}{$\begin{array}{c}\text { It requires } \\
\text { external approval }\end{array}$} & \multirow{2}{*}{ 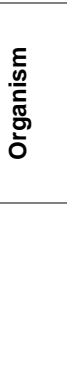 } & \multirow{2}{*}{ 站 } & \multirow{2}{*}{ 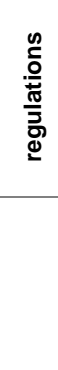 } & \multirow{2}{*}{ 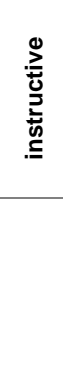 } & \multicolumn{2}{|c|}{$\begin{array}{l}\text { Superior of the } \\
\text { College }\end{array}$} & \multirow[t]{2}{*}{ Observations } \\
\hline & $\begin{array}{l}\text { YE } \\
S\end{array}$ & $\begin{array}{l}\text { DO } \\
\text { NOT }\end{array}$ & YES & $\begin{array}{l}\text { DO } \\
\text { NOT }\end{array}$ & & & & & 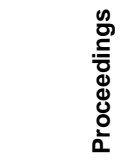 & 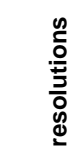 & \\
\hline $\begin{array}{l}\text { corporate bodies } \\
\text { co-government }\end{array}$ & $x$ & & $\mathrm{X}$ & & CES & & $\mathrm{X}$ & $x$ & $x$ & $\mathrm{X}$ & \\
\hline Forming unions & $\mathrm{X}$ & & & $x$ & & & $\mathrm{X}$ & & & & $\begin{array}{l}\text { There is only association of teachers } \\
\text { and workers. }\end{array}$ \\
\hline $\begin{array}{l}\text { Inclusion, } \\
\text { ethnicity, gender, } \\
\text { religion, etc. }\end{array}$ & $x$ & & $X$ & & CES & & $x$ & $x$ & $X$ & $\mathrm{X}$ & $\begin{array}{l}\text { There are rules, however it is not fully } \\
\text { materialized and unequal rights are } \\
\text { observed. }\end{array}$ \\
\hline $\begin{array}{l}\text { Rights of the } \\
\text { university } \\
\text { community }\end{array}$ & $\mathrm{X}$ & & $X$ & & CES & & $\mathrm{X}$ & $X$ & $\mathrm{X}$ & $\mathrm{X}$ & $\begin{array}{l}\text { There are rules, however it is not fully } \\
\text { materialized and unequal rights are } \\
\text { observed. }\end{array}$ \\
\hline
\end{tabular}

The results of verification of evidence shown by the indicators set for the beginning participation and representation at the University of the Armed Forces ESPE.

Source: Own Elaboration

Puga (2018), Dean of the Faculty of Economics UCE argues that govern properly a public IES, several indicators should consider. It emphasizes the general state budget, as an exogenous variable. San Martin (2018) ESPE advisor, however, refers to government systems in the areas derived from the basic functions of the university, teaching, research and links. He notes that the administrative area even though it is not part of their core functions, it is essential to consider in this system of government. Ruiz (2018) EPN adviser, points out that the dimensions of university governance, correspond to the structure and governance processes, autonomy and accountability.

\section{Dimensional perspective and approach to model university governance}

The multidimensional perspective of internal governance is derived from the quantified indicators related to exercise governance within each IES by respondents in the second part of the questionnaire.

In Figure $\mathrm{N}^{\circ} 1$ shows that even if the three IES involved in the study are public and located in the same province, they differ in the intensity with which the principles of governance are exercised. A result that matches Brunner (2011) who links the university governance with different organizational forms and models of internal operations, which are

\footnotetext{
"Visión de Futuro" Año 16, Volumen N²3 N², Julio - Diciembre 2019 - Pág. 122 - 137

URL de la Revista: http://visiondefuturo.fce.unam.edu.ar/index.php/visiondefuturo/index

URL del Documento: http://visiondefuturo.fce.unam.edu.ar/index.php/visiondefuturo/issue/view/16

ISSN 1668 - 8708 - Versión en Línea

E-mail: revistacientifica@fce.unam.edu.ar
} 
configured from its government, its management model and its relations with institutions and stakeholders in the higher education system.

The figure shows the difference in intensity is assumed that each of the principles of governance in the universities participating in the study observed. Autonomy and accountability, EPN observed more intensely than ESPE and UCE. In academic freedom, coincide with $60 \%$ intensity, EPN and UCE. Venture and institutional representation UCE reaches a higher percentage compared to EPN.

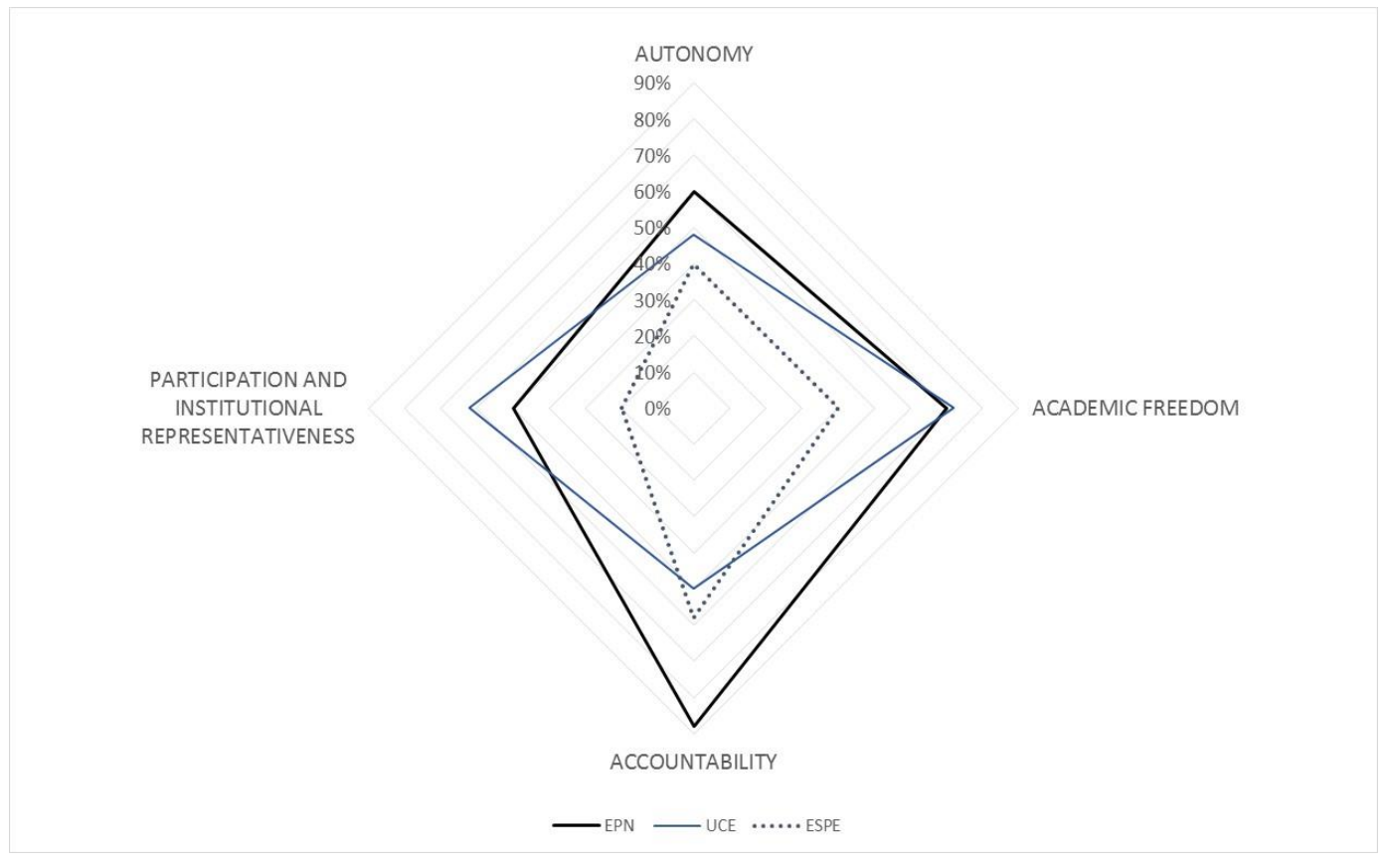

Figure $\mathbf{N}^{\circ}$ 1. Multidimensional perspective university internal governance Source: Own Elaboration

This result is derived Proposition 1: The intensity with which the principles of governance are exerted in an IES determine the different forms of organization and internal operation models.

This analysis leads to deepen the internal characteristics of each $\mathrm{HEl}$ to make an approximation of its governance model. Forms of governance differ in each IES on the model of university, its own organizational culture, the national context, the kind of leadership, among others.

Following Uauy and other authors (2014) the structures of central and local university government are considered, to identify the functions that the former exercise and the way in which they relate to those that are hierarchically below, that is to say with those that are part of local structures. The analysis was made based on the legal documents of each IES,

\footnotetext{
"Visión de Futuro" Año 16, Volumen No 23 N², Julio - Diciembre 2019 - Pág. 122 - 137

URL de la Revista: http://visiondefuturo.fce.unam.edu.ar/index.php/visiondefuturo/index

URL del Documento: http://visiondefuturo.fce.unam.edu.ar/index.php/visiondefuturo/issue/view/16

ISSN 1668 - 8708 - Versión en Línea

E-mail: revistacientifica@fce.unam.edu.ar
} 
statute, internal regulations, process manual, instructions, among others and the information provided by the advisors. The results are shown in Tables $\mathrm{N}^{\circ} 7$ and $\mathrm{N}^{\circ} 8$ for EPN and UCE, respectively.

The characteristics observed in the functions and conformation of the governing bodies of EPN and UCE; make it possible to differentiate two models of university governance, Participatory Regulation at the level of central structure and Normative Efficiency at the level of local structure. Even though, in general, the Participatory Normative model predominates in the two universities.

Analysis models in each IES internal governance described in the above tables are from the following propositions.

Proposition 2: The governance model NEP and UCE is predominantly normative level participatory in its backbone, as conformation participatory government agencies with regulatory functions primarily observed.

Proposition 3: The governance model of the EPN and UCE is predominantly normative efficiency in its level of local structure, in the measure, we observe a conformation of local government agencies efficiency with primarily normative functions.

Table $N^{\circ}$ 7. Approach to the model of university governance EPN

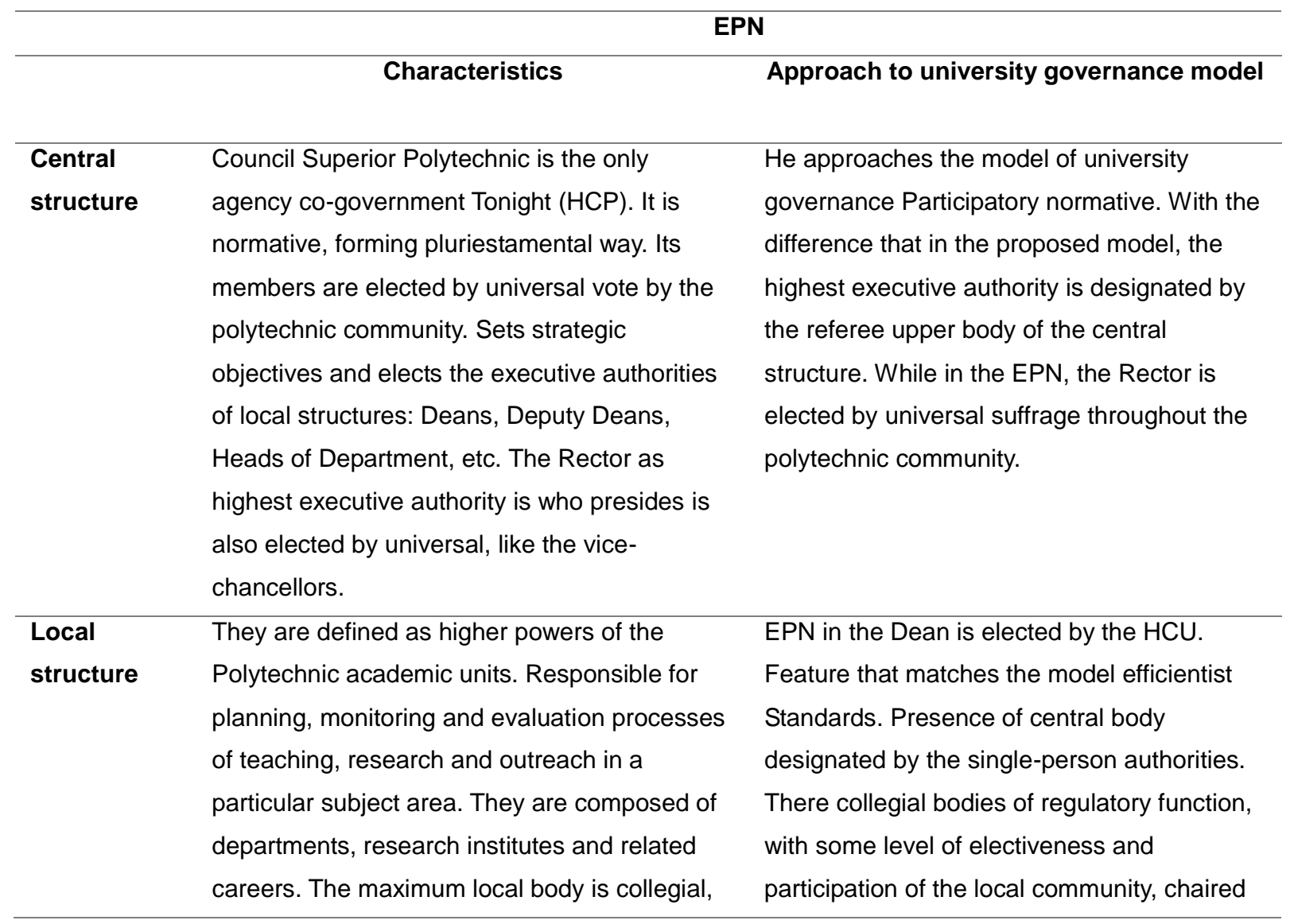

\footnotetext{
"Visión de Futuro" Año 16, Volumen N²3 N², Julio - Diciembre 2019 - Pág. 122 - 137

URL de la Revista: http://visiondefuturo.fce.unam.edu.ar/index.php/visiondefuturo/index

URL del Documento: http://visiondefuturo.fce.unam.edu.ar/index.php/visiondefuturo/issue/view/16

ISSN 1668 - 8708 - Versión en Línea

E-mail: revistacientifica@fce.unam.edu.ar
} 
The description of the characteristics observed in the central and local government structure EPN University, against which the model of university governance approaches observed.

Source: Own Elaboration

Table $N^{\circ}$ 8. Approach to the model of university governance UCE

\begin{tabular}{|c|c|c|}
\hline & \multicolumn{2}{|r|}{ UCE } \\
\hline & features & Approach to university governance model \\
\hline $\begin{array}{l}\text { Central } \\
\text { structure }\end{array}$ & $\begin{array}{l}\text { University Council is the body Academic } \\
\text { Superior. (HCU). It is normative, forming } \\
\text { pluriestamental way. Its members are } \\
\text { elected by universal suffrage by the } \\
\text { university community. Sets strategic } \\
\text { objectives. The Rector as the highest } \\
\text { executive authority, who presides, is also } \\
\text { elected by universal, like the vice- } \\
\text { chancellors. }\end{array}$ & $\begin{array}{l}\text { He approaches the model of university } \\
\text { governance Participatory normative. With the } \\
\text { difference that in the proposed model, the highest } \\
\text { executive authority is designated by the referee } \\
\text { upper body of the central structure. While the } \\
\text { UCE the Rector is elected by universal suffrage } \\
\text { throughout the polytechnic community. }\end{array}$ \\
\hline $\begin{array}{l}\text { Local } \\
\text { structure }\end{array}$ & $\begin{array}{l}\text { They defined as the higher faculties of the } \\
\text { University academic units. Responsible for } \\
\text { planning, monitoring and evaluating the } \\
\text { processes of teaching, research and } \\
\text { relationship with society in a particular } \\
\text { subject area. They are composed of related } \\
\text { careers. The maximum local body is } \\
\text { collegial, regulatory and pluriestamental } \\
\text { character. The Dean who is appointed by the } \\
\text { Rector chairs the Faculty Board. }\end{array}$ & $\begin{array}{l}\text { The Rector elects UCE in the Dean. Efficientist } \\
\text { model feature Regulatory approaches. Presence } \\
\text { of central body designated by the single-person } \\
\text { authorities. There collegial bodies of regulatory } \\
\text { function, with some level of electiveness and } \\
\text { participation of the local community, chaired by } \\
\text { centrally appointed authority. }\end{array}$ \\
\hline
\end{tabular}

Source: Own Elaboration

For ESPE, the model of university governance approaches Regulatory efficientist at the level of central structure and Executive efficientist at the level of local structure. The results are shown in Table $\mathrm{N}^{\circ} 9$.

Similarly, for ESPE are from the following propositions.

\footnotetext{
"Visión de Futuro" Año 16, Volumen No 23 N², Julio - Diciembre 2019 - Pág. 122 - 137

URL de la Revista: http://visiondefuturo.fce.unam.edu.ar/index.php/visiondefuturo/index

URL del Documento: http://visiondefuturo.fce.unam.edu.ar/index.php/visiondefuturo/issue/view/16

ISSN 1668 - 8708 - Versión en Línea

E-mail: revistacientifica@fce.unam.edu.ar
} 
Proposition 4: The governance model ESPE is predominantly eficientista normative level in its backbone, as conformation bodies eficientista government regulatory functions primarily observed.

Proposition 5: The governance model of the ESPE is predominantly eficientista level executive at its local structure, to the extent conformation agencies eficientista local government with executive functions primarily observed.

Table $N^{\circ}$ 9. Approach to the model of university governance ESPE

\begin{tabular}{|c|c|c|}
\hline & \multicolumn{2}{|c|}{ ESPE } \\
\hline & features & Approach to university governance model \\
\hline $\begin{array}{l}\text { Central } \\
\text { structure }\end{array}$ & $\begin{array}{l}\text { University Council is the academic collegiate } \\
\text { body superior co-government (HCU). It is } \\
\text { normative, forming pluriestamental way. Its } \\
\text { members are elected by universal suffrage } \\
\text { by the university community. Sets strategic } \\
\text { objectives. The Rector as the highest } \\
\text { executive authority who presides. He is } \\
\text { appointed by the Chief of the Joint } \\
\text { Command of the Armed Forces, as the vice- } \\
\text { chancellors. }\end{array}$ & $\begin{array}{l}\text { He approaches the model of university governance } \\
\text { Efficientist Regulatory type. With the difference that } \\
\text { in this model, the maximum external executive } \\
\text { authority is designated by the referee body. While } \\
\text { the ESPE, the Rector is appointed by the Chief of } \\
\text { the Joint Command of the Armed Forces, as the } \\
\text { vice-chancellors. Completely outside authority to } \\
\text { university structure. }\end{array}$ \\
\hline $\begin{array}{l}\text { Local } \\
\text { structure }\end{array}$ & $\begin{array}{l}\text { The local structure matrix consisting of } \\
\text { Departments, as higher academic units of } \\
\text { the University. Responsible for coordinating, } \\
\text { monitoring and evaluating the processes of } \\
\text { teaching, research and relationship with } \\
\text { society in a particular subject area. The } \\
\text { Department Council is the highest collegiate } \\
\text { body, composed of the director who presides } \\
\text { Department and four teachers proposed by } \\
\text { director and appointed by the Rector. The } \\
\text { Rector appoints department Director. }\end{array}$ & $\begin{array}{l}\text { In the ESPE, the Rector appoints the local } \\
\text { authorities. } \\
\text { Only in the highest collegiate body meets the } \\
\text { characteristic of electivity and pluriestamental. At } \\
\text { the local level, the Rector appoints the members of } \\
\text { the collegiate bodies. The Department Council is } \\
\text { not of a normative nature, but rather an executive } \\
\text { one. That is, those responsible for the } \\
\text { implementation of the regulations, defined by the } \\
\text { central body. The model is close to an Executive } \\
\text { Efficientist. }\end{array}$ \\
\hline
\end{tabular}

The description of the observed characteristics observed in the central and local university governance structure of the ESPE, against which the model of university governance approaches.

Source: Own Elaboration

The marked difference between governance models ESPE and EPN, UCE, has its origin in the LOES approved in 2010. It gives an exception to the rest of the country IES, regarding the designation of the authorities. Article 55 determines that the academic authorities of the ESPE will be chosen according to what its statutes. Transitional Provision

\footnotetext{
"Visión de Futuro" Año 16, Volumen N²3 N², Julio - Diciembre 2019 - Pág. 122 - 137

URL de la Revista: http://visiondefuturo.fce.unam.edu.ar/index.php/visiondefuturo/index

URL del Documento: http://visiondefuturo.fce.unam.edu.ar/index.php/visiondefuturo/issue/view/16

ISSN 1668 - 8708 - Versión en Línea

E-mail: revistacientifica@fce.unam.edu.ar
} 
Twenty-second is determined that the wording of the statute observe the purposes and objectives, in line with the policies defined by the Ministry of National Defense.

The results agree with the assessment made advisers of the three educational institutions, statements related to the axes: functions of the bodies of university governance and shaping agencies university governance, as appropriate to the proposed Uauy and others (2014).

The observed features are not absolute, in the exercise of university government dominated some more than others and configure dynamic models of governance, however prevalent one over the other models. Figure $\mathrm{N}^{\circ} 2$ shows the model of university governance to each IES because of the assessment of the assessors approaches concerning the shape and functions of government agencies academic configuring different models of university governance.

Conformation of university governing bodies

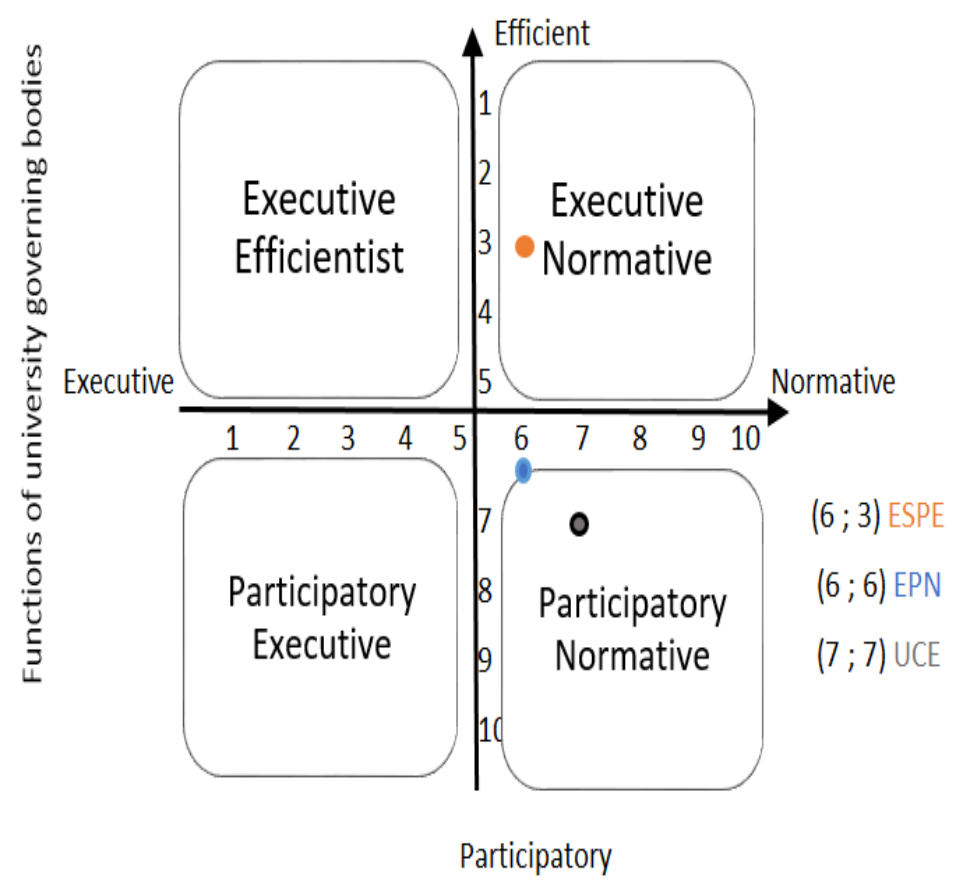

Figure $N^{\circ}$ 2. Sample university governance

Source: Own Elaboration

\section{CONCLUSION}

While all three IES involved in the study are public and located in the same province, they differ in the way in which the four principles of governance, autonomy, academic

\footnotetext{
"Visión de Futuro" Año 16, Volumen No 23 N², Julio - Diciembre 2019 - Pág. 122 - 137

URL de la Revista: http://visiondefuturo.fce.unam.edu.ar/index.php/visiondefuturo/index

URL del Documento: http://visiondefuturo.fce.unam.edu.ar/index.php/visiondefuturo/issue/view/16

ISSN 1668 - 8708 - Versión en Línea

E-mail: revistacientifica@fce.unam.edu.ar
} 
freedom, accountability, participation and institutional representation are exercised. This intensity determines different forms of organization and internal operation models.

So the characterization of the universities participating in the study regarding the different types of university governance, is from the functions exercised by agencies that are on the cusp of the university structure (central structure) and how relate to those hierarchically below (local structure).

Hence, it is concluded that the governance model EPN and UCE is predominantly normative level participatory in its backbone, as conformation participatory government agencies with regulatory functions primarily observed. At local level, the regulatory structure dominates eficientista, since the formation of local government bodies with functions primarily eficientista regulations.

The governance model ESPE is predominantly eficientista normative level in its backbone, as conformation bodies eficientista government regulatory functions primarily observed. At local level eficientista executive structure dominates, since conformation agencies eficientista local government executive functions primarily observed.

The development of the subject is of national interest so required opening existed, although this study was limited only to the population of public universities in the province of Pichincha, home to most of the student population. However, in a second phase covering study in other provinces will expand, to self-financed and co-financed IES.

It is important to recognize that from 2008, the Ecuadorian SES has been undergoing a process of transformation to a substantial improvement of educational quality, so it is important to supplement the present study to identify the prevailing model of governance in the SES in their whole and its impact on behavior observed in the IES. From these results, ensure participatory environments based on the recognition of the ability of universities to fulfill its historical mission and deliver relevant and timely responses to society.

\section{REFERENCES}

Please refer to articles in Spanish Bibliography.

\section{BIBLIOGRAPHCIAL ABSTRACT}

Please refer to articles Spanish Biographical abstract.

\footnotetext{
"Visión de Futuro" Año 16, Volumen No 23 No2, Julio - Diciembre 2019 - Pág. 122 - 137

URL de la Revista: http://visiondefuturo.fce.unam.edu.ar/index.php/visiondefuturo/index

URL del Documento: http://visiondefuturo.fce.unam.edu.ar/index.php/visiondefuturo/issue/view/16

ISSN 1668 - 8708 - Versión en Línea

E-mail: revistacientifica@fce.unam.edu.ar
} 